\title{
Retinoblastoma pT2a TNM Finding v8
}

National Cancer Institute

\section{Source}

National Cancer Institute. Retinoblastoma pT2a TNM Finding v8. NCI Thesaurus. Code C140718.

Concomitant focal choroidal invasion and pre-or intralaminar involvement of the optic nerve head. (from AJCC 8th Ed.) 